\title{
Japan prepares to pitch for international fusion reactor
}

\section{David Cyranoski, Tokyo}

Japan has taken another tentative step towards hosting the International Thermonuclear Experimental Reactor (ITER), a collaborative project to develop nuclear fusion as an energy source.

Earlier this month, the country's Atomic Energy Commission approved a report supporting construction of the multibillion dollar project in Japan. But the commission also emphasized that hosting the facility must not harm existing Japanese research programmes.

The commission signalled its intention to bid for the ITER late last year, and its report endorses the project's technological feasibility, safety and scientific importance. The plans will probably be submitted early next month to Japan's top scientific panel, the Council for Science and Technology Policy (CSTP), which is chaired by the prime minister.

If the council approves the plan, Japan will select a suitable site and put it forward in time for the mid-2001 deadline set by the ITER consortium. Other possible candidate sites for the experiment are in Canada and France, although neither country is as well placed as Japan to shoulder the two-thirds of construction costs likely to fall on the host.

A lack of natural energy resources makes Japan the obvious place for the project, says Hiroyuki Yoshikawa, president of the National Institute of Advanced Industrial Science and Technology and chair of the panel that drew up the commission's report. "Japan's energy future is with fusion," he says.

But there are already several fusion projects under way in Japan, which researchers are loath to see cut back. The Japan Atomic Energy Research Institute (JAERI) and the National Institute for Fusion Science (NIFS) are both investigating doughnut-shaped plasma devices that would magnetically confine plasma and heat it to the temperatures at which fusion would occur.

The JAERI is working with 'tokamak' reactors, of which the ITER would be the largest ever built, whereas NIFS is concentrating on helical devices, which use a different technique to create and sustain their magnetic fields. Another approach under investigation, called inertial confinement fusion, relies on a powerful laser to create fusion in a tiny pellet of fuel.

Competition between the approaches has intensified since they all fell under control of the education ministry, as a result of January's government reorganization (see Nature $408,757 ; 2000)$.

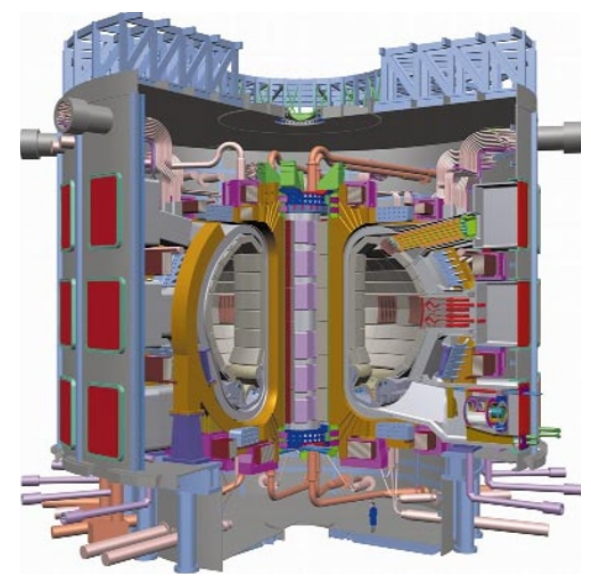

Getting there: Japan's plan to host ITER may be endorsed by its top science panel next month.

"Scientifically speaking, [the ITER] is clearly something we should do, but splitting up the budget has been a problem," says Tatsuhiko Yamanaka, director of Osaka University's laser fusion research centre, home of Japan's main inertial fusion programme.

As a result, Yoshikawa's report backs ITER construction only if funding for all of the other fusion projects is maintained.

Some believe that Japan will be able to do that. "Japan will put money where it needs to," says Masato Nakamura, director of the government's fusion energy office. The estimated ITER budget of $¥ 400$ billion (US\$3.3 billion) would fit easily in Japan's plan to spend an average of $¥ 4.8$ trillion a year on research and development, says Yoshikawa.

But others are less certain. "There is still no consensus within Japan about how to run such a project," says Atsuo Iiyoshi, president of Chubu University in Nagoya, a former director of NIFS and a member of the panel. He says that extra materials research needed to make the ITER work could cost $¥ 100$ billion, and he questions Japan's ability to coordinate the project effectively.

Iiyoshi says the commission's report reflects some of this caution, and stops short of a full-scale endorsement of bringing the project to Japan. "It's basically just passed the buck to the CSTP," says Iiyoshi.

But there is plenty of enthusiasm for fusion power at higher levels of government in Japan. The country will pursue it as the "ultimate" energy source, says Hiroo Imura, a former president of Kyoto University who sits on the CSTP. He says: "The council will have to consider carefully the budget allocation to various types of nuclear fusion research when deciding whether to support the ITER."

\section{Swiss proteomics company aims to make big impact}

\section{Alison Abbott, Munich}

Swiss proteomics pioneers hope to make a big splash in the commercial world when their new company, GeneProt, opens its first facility in Geneva on 26 April.

The company hopes to become one of the main players in proteomics, having raised US\$122 million in capital since it was founded a year ago. It is now building a second facility at Princeton, New Jersey.

GeneProt will employ 100 people, and aims to discover proteins that could provide targets for drug development or diagnostics, as well as ones that could be used directly as therapeutics. Its researchers will separate tens of thousands of proteins from diseased and healthy tissues, using gel filtration and chromatography, and identify them using a bank of 51 mass spectrometers.

Analysis will be supported by a Compaq computer, which Denis Hochstrasser, one of GeneProt's founders, says will deliver more power than is available to any other proteomics company.

Hochstrasser and the other founders of GeneProt have been making Geneva a centre of proteomics research since the 1980 s. He is a vocal proponent of free public access to genomic and protein information, and says that GeneProt will make information publicly available about the "many proteins, such as housekeeping proteins, which have no commercial value".

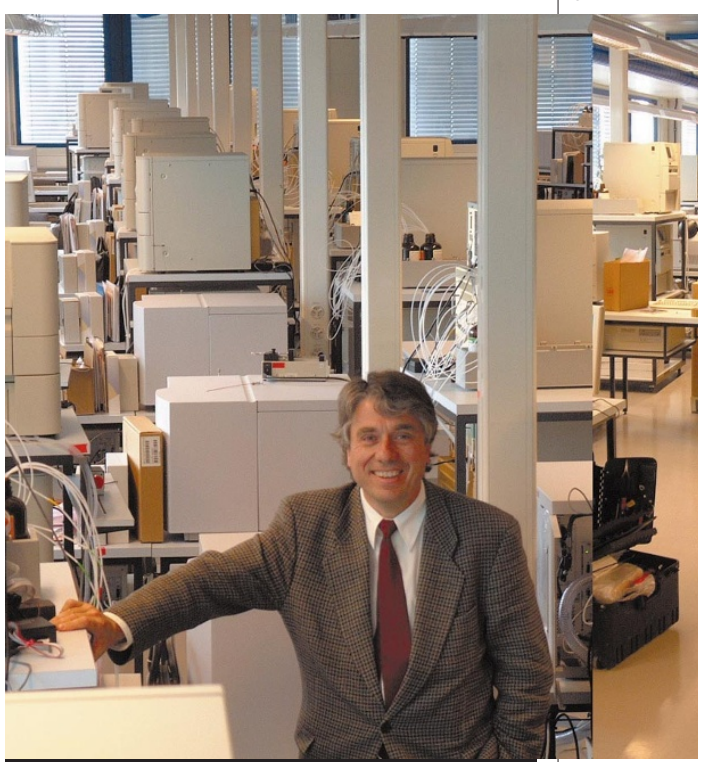

Free thinker: Hochstrasser says he will make much of GeneProt's data freely available. 